\title{
Potential Low-Level Waste Disposal Limits for Activation Products from Fusion
}

W. E. Kennedy, Jr.

R. A. Peloquin

September 1983

Prepared for the U.S. Department of Energy under Contract DE-AC06-76RLO 1830

Pacific Northwest Laboratory Operated for the U.S. Department of Energy by Battelle Memorial Institute 


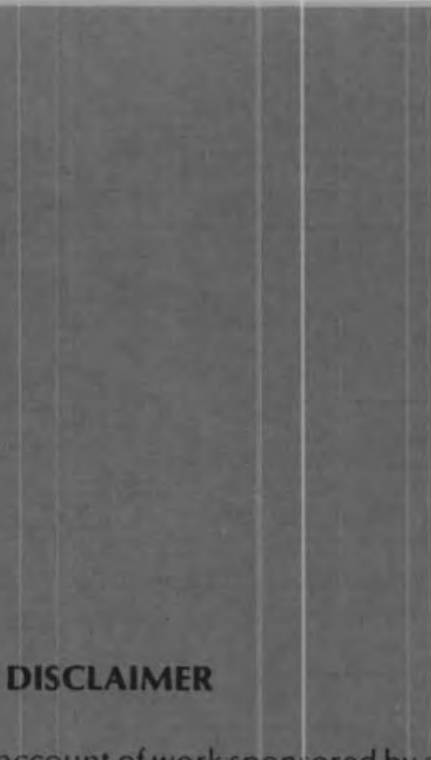

This report was prepared as an account of work spon:iored by an agency of the United States Government. Neither the United Stales Government nor any agency thereof, nor any of their employees, makes any warranty, express or implied, or assumes any legal liability or responsibility for the accuracy, completeness, or usefulness of any information, apparatus, product, or process disclosed, or represents that its use would not infringe privately owned rights. Reference herein to any specific commercial product, process, or service by trade name, trademark, manufacturer, or otherwije, does not necessarily constitute or imply its endorsement, recommendation, or favoring by the United States Government or any agency thereof. The views and opinions of authors expressed herein do not necessarily state or neflect those of the United States Government or any agency thereof.

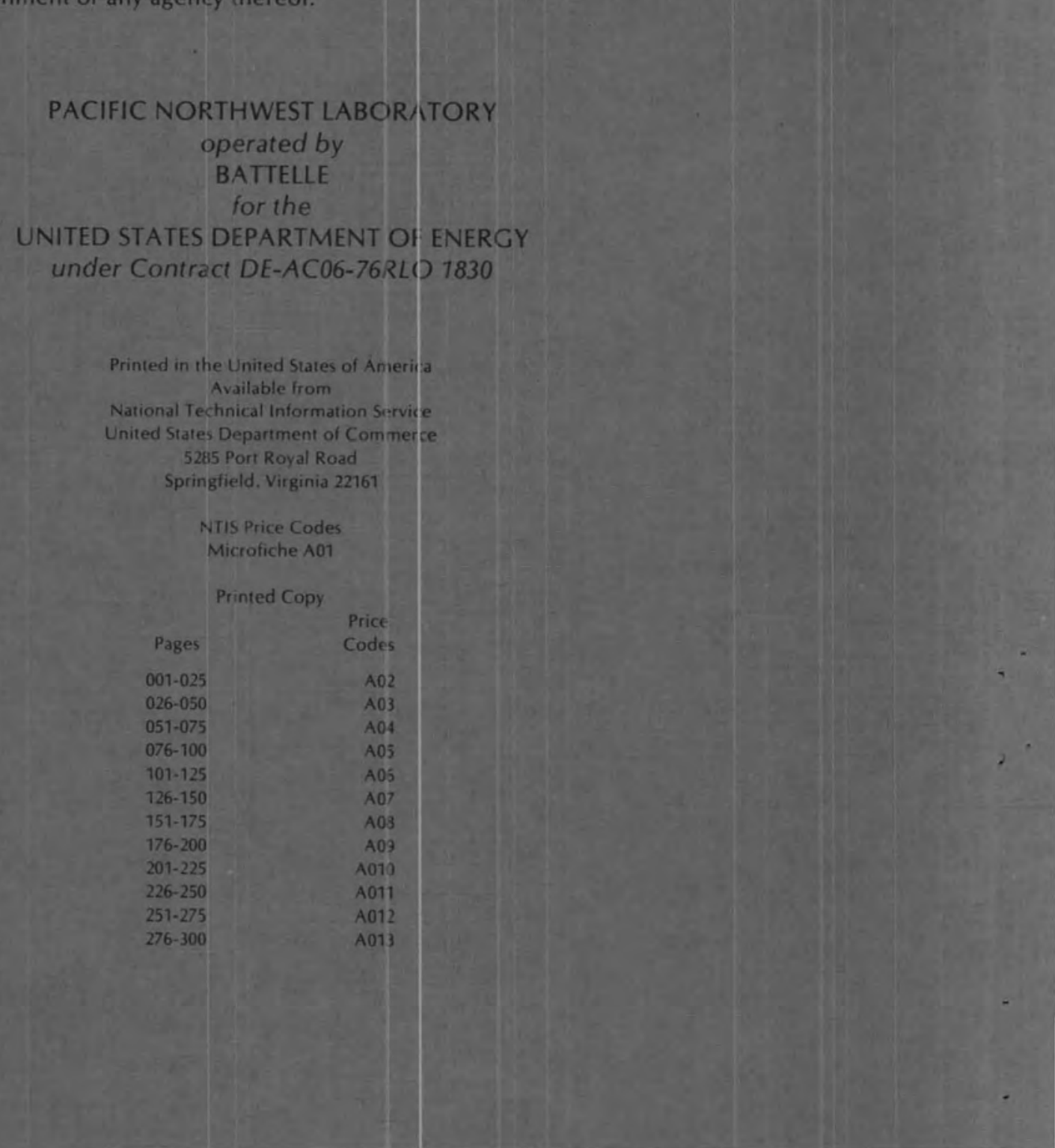


A Research Report for the Hanford Engineering and Development Laboratory

POTENTIAL LOW-LEVEL WASTE DISPOSAL LIMITS FOR ACTIVATION PRODUCTS

FROM FUSION

W. E. Kennedy, Jr.

R. A. Peloquin

September 1983

Prepared for the U.S. Department of Energy under Contract DE-AC06-76RLO 1830

Pacific Northwest Laboratory Richland, Washington 99352 


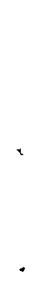




\section{ABSTRACT}

Hanford Engineering Development Laboratory (HEDL) scientists are involved in studies considering alternative construction materials for the first wall of commercial fusion reactors. To permit a comparison of radioactivity levels, both the level of activation and an acceptable $1 \mathrm{imit}$ for the radionuclides present must be known. Generic material composition guidelines can be developed using the U.S. Nuclear Regulatory Commission (NRC) regulations governing the near-surface disposal of low-level radioactive wastes. These regulations consider wastes defined as containing source, special nuclear, or by-product materials arising from research, industrial, medical, and nuclear fuel-cycle activities. However, not all of the activation products produced in low-level wastes from fusion reactors are considered by the NRC in their regulations. The purpose of this report is to present potential low-level waste-disposal 1 imits for ten radionuclides resulting from fusion reactor operations that are not considered in the NRC low-level waste regulations. These potential limits will be used by HEDL scientists to complete their generic material composition guidelines for the first wall of commercial fusion reactors. 


\section{TABLE OF CONTENTS}

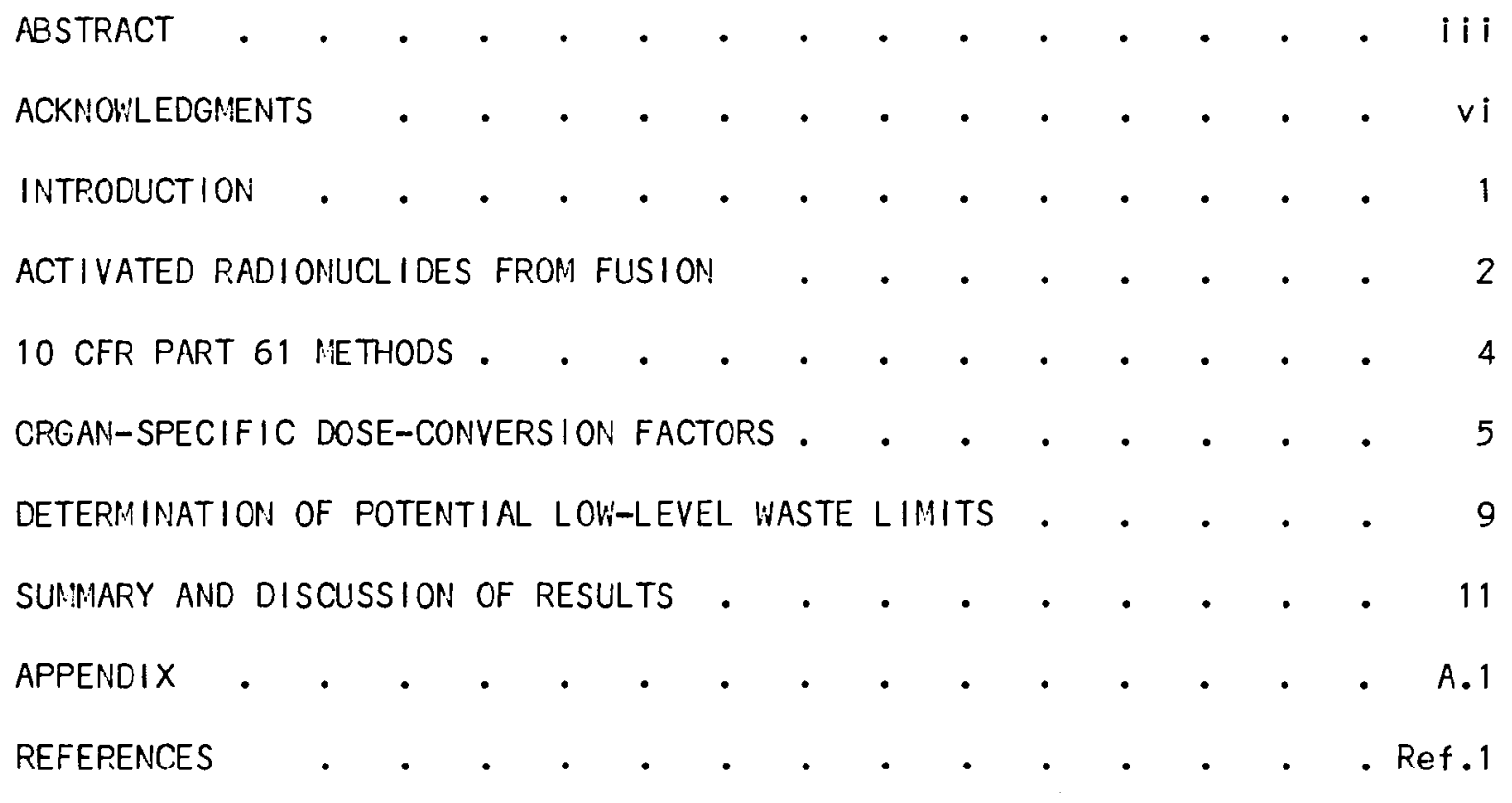




\section{IABLES}

1 STARFIRE First-Wall Activation Products That are not

Included in 10 CFR Part 61

2 Energy Absorbed (MeV) per Disintegration In Adult Organs

for Activation Products From Fusion . . . . . . . 7

3 Scenario-Specific Organ-Dose Conversion Factors . $\quad$ - $\quad$ - 8

4 Potential Low-Level Waste-Disposal Limits "or Fusion Wastes .10

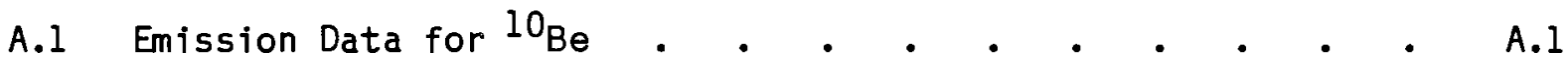

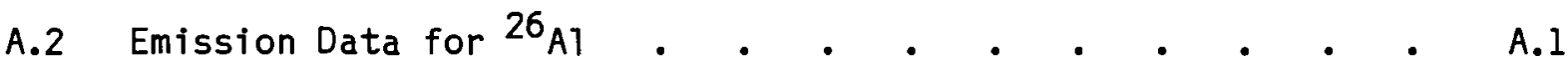

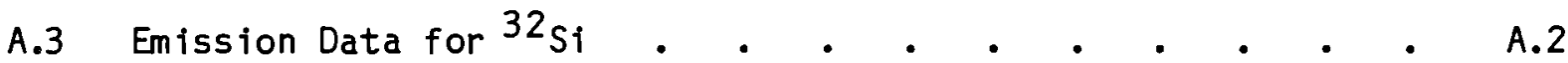

A.4 Emission Data for ${ }^{53} \mathrm{Mn}$. $\quad$. $\quad$. . . . . . . . . . A.2

A.5 Emission Data for ${ }^{92} \mathrm{Nb}$. . . • • • • • . . A.2

A.6 Emission Data for ${ }^{93} \mathrm{Zr}$.

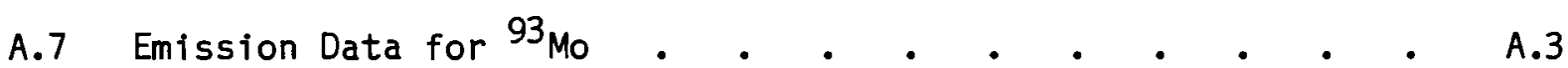

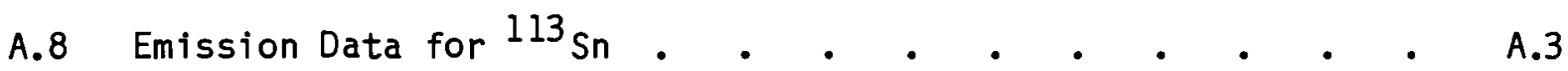

A.9 Emission Data for ${ }^{123} \mathrm{Sn}$.

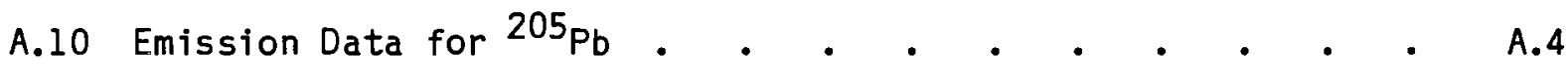




\section{ACKNOWLEDGMENTS}

The authors would like to thank all of those individuals who helped make this study possible. We would like to especially recognize the efforts of Norma Van Houten in providing typing support during the preparation and review of the manuscript. We would also like to express appreciation of the guidance and assistance provided by Dr. F. M. Mann of the Hanford Engineering and Development Laboratory. 


\section{INTRODUCTION}

On December 27, 1982, the U.S. Nuclear Regulatory Commission (NRC) issued a final version of a new regulation governing the disposal of lowlevel radioactive wastes (10 CFR Part 61) (Federal Register 1982; U.S. NRC 1982). The wastes considered in the regulation are generally defined as containing source, special nuclear, or by-product materials. These wastes originate from a variety of places including nuclear fission fuel-cycle facilities, university and industrial research centers, medical diagnostic and treatment facilities, and waste-disposal and decontamination companies. Low-level wastes originating from fusion reactor operation were not included. The purpose of this report is to present potential low-level waste disposal limits for ten radionuclides, resulting from fusion-reactor operation, that are not currently mentioned in 10 CFR Part 61.

The radionuclides of concern in this report were identified by Hanford Engineering and Development Laboratory (HEDL) scientists as being of potential waste management importance by an evaluation of alternative materials for construction of the first wall of commercial fusion reactors (U.S. DOE 1983 a; U.S. DOE 1983b). In order to tailor the composition of a first-wall material so that an acceptable low level of radioactivity will be produced, both the level of activation and an acceptable limit for the activation of each element in the material must be known. The evaluation compared the potential quantities of activated materials resulting from the operation of reference fusion reactors to the disposal concentrations allowed by the NRC. Because of large differences in the construction materials neutron energies and absorption cross sections between fusion and fission reactors, differences in the types of activated radionuclides were found. Of particular concern were the ten radionuclides that did not have direct disposal limits set by the NRC.

The low-level waste disposal limits developed by the NRC are based on a complex exposure scenario analysis. It was not our intent to duplicate their entire analysis, thus we simply developed the potential disposal 
1 imits for the fusion-activation radionuclides using a ratio technique based on ${ }^{59} \mathrm{Ni}$, a long-lived activation product considered by the NRC. As a check of the adequacy of our technique, we compared disposal limits developed by our method to those reported by the NRC for ${ }^{60}$ Co and ${ }^{63} \mathrm{Ni}$. The comparison shows good agreement.

This report contains descriptions of: 1) the radionuclides of potential low-level waste management interest from fusion that are not included in 10 CFR Part 61,2) the methods used by the NRC in developing the limits shown in 10 CFR Part 61 ,3) the calculaticin of organ-specific doseconversion factors for the radionuclides of interest, 4) the ratio method used for developing the potential low-level waste disposal limits for the radionuclides of interest, and 5) a summary and ifiscussion of our results.

\section{ACTIVATED RADIONUCLIDES FROM FUSION}

Scientists at HEDL are involved in calculations to determine the activation of 27 elements present in the first-wall material of a reference fusion reactor (U.S. DOE $1983 \mathrm{a}$; U.S. DOE $1983 \mathrm{~b}$ ). Three categories of activation products are of potential interest:

- short half-life materials (minutes to hours) for exposures during accident conditions

- medium half-life materials (days to weeks) for occupational exposure estimates resulting from maintenance activities

- very long half-life materials (years to centuries and longer) where waste disposal concerns are important.

Both the level of activation and an acceptable limit for activation must be known in order to tallor the composition of a first-wall material to assure that an acceptably low level of radioactivity will be produced. It is not possible to provide meaningful 1 imits for accident and maintenance situations because they will depend heavily on detailed engineering 
assumptions and the plant layout. It is possible, however, to calculate generic, material composition 1 imits based on the quantitative limits for low-level waste disposal set by the NRC in 10 CFR Part 61 (Federal Register 1982).

The conceptual design selected by HEDL scientists for analysis was the STARFIRE Tokamak design (U.S. DOE 1983). This reactor was assumed to be the tenth commercial fusion reactor in operation, implying an advanced and mature technology. Activation levels were calculated for a two-year exposure at the STARFIRE first-wall position for 27 elements ( $L i, B e, B, C$, $\mathrm{N}, \mathrm{O}, \mathrm{Mg}, \mathrm{Al}, \mathrm{Si}, \mathrm{P}, \mathrm{S}, \mathrm{Ti}, \mathrm{V}, \mathrm{Cr}, \mathrm{Mn}, \mathrm{Fe}, \mathrm{Co}, \mathrm{Ni}, \mathrm{Cu}, \mathrm{Zr}, \mathrm{Nb}, \mathrm{Mo}, \mathrm{Sn}, \mathrm{H} f$, $\mathrm{Ta}, W$, and $\mathrm{Pb}$ ) for various cooling times.

Most of the activation products determined in the HEDL analys is had corresponding low-level waste disposal limits in 10 CFR Part 6l. The exceptions and their half-lives are shown in Table 1.

TABLE 1. STARFIRE First-Wall Activation Products That Are Not Included in 10 CFR Part 61

Radionuclide

$10 \mathrm{Be}$

${ }^{26} \mathrm{~A} 1$

${ }^{32} \mathrm{Si}$

$53 \mathrm{Mn}$

$92 \mathrm{Nb}$

${ }^{9}{ }^{2} \mathrm{r}+D^{(b)}$

$9^{3} \mathrm{Mo}$

$113 \mathrm{Sn}$

$123 \mathrm{Sn}$

$205 \mathrm{~Pb}$
Hal f-Life

(Years)

$1.6 E+6^{(a)}$

$7.3 E+5$

2. $8 \mathrm{E}+2$

3. $8 \mathrm{E}+6$

1. $6 \mathrm{E}+8$

$1.5 E+6$

3. $5 E+3$

3. $2 \mathrm{E}-1$

3.5E-1

$1.4 \mathrm{E}+7$

(a) Where $1.6 \mathrm{E}+6=1.6 \times 10^{6}$

(b) $+D$ means plus short-lived daughter products. 
To permit a complete evaluation of material composition limits, an evaluation of the potential low-level waste dispcisal limits for the radionuclides shown in Table 1 is required. This evaluation is described in the following sections of this report.

\section{CFR PART 61 METHODS}

The NRC uses a radiation exposure scenario analysis in the Draft Environmental Impact Statement on 10 CFR Part 61 (1981) to determine nearsurface disposal 1 imits. They have identified four radiation exposure scenarios for human intrusion (U.S. NRC 1981, ApF. H, P. H-15):

- Intruder-Construction Scenario. An individual excavates at an abandoned disposal site to bulld a house.

- Intruder-Discovery Scenario. This scenario is a subset of the intruder-construction scenario and also invalves excavation into a closed site. The time over which the excavation proceeds is reduced compared to the intruder-construction scenario.

- Intruder-Agriculture Scenario. An individual lives in a house built on a closed disposal site surrounded by contaminated soil resulting from the intruder-construction scenario. The individual consumes vegetables grown in the contaminated soil.

- Intruder-Well Scenario. An individual uses contaminated water from an onsite well.

The disposal 1 imits that result are based on a 500-mrem total-body exposure to the maximum-exposed individual (intruder). Only two of the four scenarios considered actually control the disposal 1 imits for radionuclides in activated metals, such as would result from activated fusion-reactor first-wall materials. These are the Intruder-Construction scenario and the Intruder-Agriculture scenario. The Intruder-Construction scenario controls the disposal 1 imits for radionuclides with a dominant exposure 
pathway resulting from direct penetrating radiation. The IntruderAgriculture scenario controls the disposal Ilmits for radionuclides with a dominant exposure pathway resulting from ingestion of fruit and vegetable crops grown in contaminated soil.

The disposal IImits shown in Tables 1 and 2 of 10 CFR Part 61 (Eederal Register 1982) contain a radioactive decay correction term. For $\mathrm{Class} \mathrm{A}$ wastes, or those wastes that have $\mathrm{minimum}$ stability requirements and low activity levels, the concentrations shown reflect 100 years of radioactive decay that would occur during an institutional control period following site closure. For Class C wastes, or wastes having a stable waste form, a package with integrity, and a higher level of activity, the concentrations reflect 500 years of radioactive decay. Th is decay period for $\mathrm{Class} C$ wastes is to account for the stabllity of the waste form (such as provided by activated metals) and the integrity of the waste package.

\section{ORGAN-SPECIFIC DOSE-CONVERSION FACTORS}

To determine low-level waste disposal I imits, the NRC used an exposure pathway to man analysis as described in the Draft Environmental Impact Statement on 10 CFR Part 61 (U.S. NRC 1981). This analysis used dose conversion factors derived from Regulatory Guide 1.109 (U.S. NRC 1977), which were based on the International Commission on Radiological Protection (ICRP) Publication 2 dosimetry methods (ICRP 1959). To permit an evaluation of the potential disposal ilimits for the fusion radionuclides, compatible dose-conversion factors had to be developed. The dose-conversion factors rely on the energy absorbed per disintegration in adult organs for each radionuclide. In the equations presented by the ICRP (1959), the effective energy term has various forms depending upon the type of radiation considered (i.e., X-rays, gamma-rays, beta particles, alpha particles, electrons, or atomic recolis). 
Although various methods have been used for determining the effective beta energy, a simple empirical equation produces results accurate to within about 5\% for most 1arge organs (ICRP 1959). The equation is:

$$
E=0.33 E_{m} f\left(1-\frac{z^{1 / 2}}{50}\right)\left(1+\frac{E_{m}^{1 / 2}}{4}\right)
$$

where $E$ - the total energy absorbed in a body organ per disintegration of a radionuclide (MeV)

$E_{m}$ - maximum energy of disintegration type colosidered (MeV)

$f$ - fraction of the disintegrations considered

$Z$ - atomic number of the radionuclide emitting the beta particle.

For gamma radiation, the equation is:

$$
E=E_{m} f\left(1-e^{-\sigma x}\right)
$$

where $E, E_{m}$, and $f$ are the same as defined for Equation 1 and where $\sigma$ - total coefficient of absorption minus the compton scattering coefficient $\left(\mathrm{cm}^{-1}\right)$ for the given photon energy

$x$ - the effective radius of the body organ containing the radionuclide. 
For $K$ and $L$ shall capture $X-r$ ays, the equation is:

$$
E=f \eta\left(1-e^{-\sigma x}\right)
$$

where $E, f, \sigma$, and $x$ are the same as previously defined, and where $\eta$ - binding energy of the daughter element.

The effective radi $i$ of the adult organs considered in this study are $30 \mathrm{~cm}$ for total body, $5 \mathrm{~cm}$ for bone, $10 \mathrm{~cm}$ for 1 ungs, and $5 \mathrm{~cm}$ for G.I. Tract (lower large intestine). Listings of the emission data for the radionuclides shown in Table 1 are given in Tables A.1-A.10 in the Appendix. The calculated energy absorbed per disintegration for the ten fusion radionuclides are shown in Table 2 for four organs of interest.

IABLE 2. Energy Absorbed (MeV) per Disintegration In Adult
Organs for Activation Products from Fusion

Total Body Bone Lungs G.I. Tract

Radionuclide (30-cm Radius) (5-cm Radius) (10-cm Radius) (5-cm Radius)

\begin{tabular}{|c|c|c|c|c|}
\hline $\begin{array}{l}10 \mathrm{Be} \\
26 \mathrm{Al} \\
{ }^{32} \mathrm{Si}\end{array}$ & $\begin{array}{l}2.1 \mathrm{E}-1^{(b)} \\
1.4 \mathrm{E}+0 \\
7.2 \mathrm{E}-2\end{array}$ & $\begin{array}{l}1.0 \mathrm{E}+0 \\
2.4 \mathrm{E}+0 \\
3.6 \mathrm{E}-1\end{array}$ & $\begin{array}{l}2.1 \mathrm{E}-1 \\
8.3 \mathrm{E}-1 \\
7.2 \mathrm{E}-2\end{array}$ & $\begin{array}{l}2.1 \mathrm{E}-1 \\
6.3 \mathrm{E}-1 \\
7.2 \mathrm{E}-2\end{array}$ \\
\hline $\begin{array}{l}53 \mathrm{Mn} \\
92 \mathrm{Nb} \\
93 \mathrm{Zr}+\mathrm{D}(\mathrm{c})\end{array}$ & $\begin{array}{l}7.9 E-3 \\
1.1 E+0 \\
2.3 E-2\end{array}$ & $\begin{array}{l}3.4 \mathrm{E}-2 \\
1.1 \mathrm{E}+0 \\
1.1 \mathrm{E}-1\end{array}$ & $\begin{array}{l}7.9 \mathrm{E}-3 \\
5.7 \mathrm{E}-1 \\
1.9 \mathrm{E}-2\end{array}$ & $\begin{array}{l}7.9 E-3 \\
3.8 E-1 \\
1.9 E-2\end{array}$ \\
\hline $\begin{array}{r}93 \mathrm{Mo} \\
113 \mathrm{Sn} \\
123 \mathrm{Sn}\end{array}$ & $\begin{array}{l}1.9 \mathrm{E}-2 \\
7.7 \mathrm{E}-2 \\
5.2 \mathrm{E}-1\end{array}$ & $\begin{array}{l}5.4 E-2 \\
7.5 E-2 \\
2.6 E+0\end{array}$ & $\begin{array}{l}1.9 \mathrm{E}-2 \\
4.1 \mathrm{E}-2 \\
5.2 \mathrm{E}-1\end{array}$ & $\begin{array}{l}1.9 \mathrm{E}-2 \\
2.1 \mathrm{E}-2 \\
5.2 \mathrm{E}-1\end{array}$ \\
\hline $205 \mathrm{~Pb}$ & $6.8 \mathrm{E}-2$ & $2.5 E-2$ & $6.8 \mathrm{E}-2$ & $6.8 \mathrm{E}-2$ \\
\hline
\end{tabular}

(a) Based on the ICRP-2 (1959) dosimetry models with spherical organs of the radil shown.

(b) Where $2.1 \mathrm{E}-1=2.1 \times 10^{-1}$.

(c) $+D$ means plus short-lived daughters. 
The energy-absorbed-per-disintegration values 1 isted in Table 2 are next used in a special organ data library to calculate scenario-specific dose-conversion factors. The scenario considered is the IntruderAgriculture scenario as described in the draft ervironmental impact statement on 10 CFR Part 61 (U.S. NRC 1981). This scenario considers ingestion by the maximum-exposed individual of half of the fruit and vegetable diet grown in contaminated soil. The PABLM (Napier, Kennedy, Jr. and Soldat) computer program was used to calculate the scenario-specific organ-dose factors shown in Table 3.

IABLE 3. Scenario-Specific Organ-Dose Conversion Factors

\begin{tabular}{|c|c|c|c|c|}
\hline Radionuclide & $\begin{array}{l}\text { 50-Year Dose } \\
\text { Iotal Body }\end{array}$ & $\begin{array}{l}\text { Commitm } \\
\text { Bone }\end{array}$ & $\begin{array}{l}\text { nt (mren } \\
\text { _Lung }\end{array}$ & $\begin{array}{l}y r / \mu(\mathrm{Ci} / \mathrm{g}) \\
G I(L L I)\end{array}$ \\
\hline $\begin{array}{l}10 \mathrm{Be} \\
26 \mathrm{Al} \\
{ }^{32} \mathrm{Si}\end{array}$ & $\begin{array}{l}5.5 E+2(a) \\
2.1 E+5 \\
8.6 E+3\end{array}$ & $\begin{array}{c}2.2 E+4 \\
- \\
-\end{array}$ & $\begin{array}{r}-(b) \\
1.3 E+6 \\
6.4 E+4\end{array}$ & $\begin{array}{l}2.1 E+5 \\
2.1 E+5 \\
3.4 E+3\end{array}$ \\
\hline $\begin{array}{l}53 \mathrm{Mn} \\
92 \mathrm{Nb} \\
93 \mathrm{Zr+D}(\mathrm{C})\end{array}$ & $\begin{array}{l}6.3 E+3 \\
1.2 E+4 \\
1.8 E+3\end{array}$ & $\begin{array}{c}-\overline{3 E+4} \\
6.3 \mathrm{E}+3\end{array}$ & - & $\begin{array}{l}4.5 E+3 \\
7.5 E+6 \\
8.1 E+3\end{array}$ \\
\hline $\begin{array}{r}93 \mathrm{Mo} \\
113 \mathrm{Sn} \\
123 \mathrm{Sn}\end{array}$ & $\begin{array}{l}1.5 E+5 \\
1.8 E+3 \\
3.7 E+3\end{array}$ & $\begin{array}{c}-\overline{2} \\
3.2 E+4 \\
1.5 E+5\end{array}$ & $\begin{array}{l}\text { - } \\
\text { - }\end{array}$ & $\begin{array}{l}1.0 E+4 \\
1.1 E+5 \\
3.6 E+5\end{array}$ \\
\hline $205 \mathrm{~Pb}$ & $8.3 E+5$ & $2.0 E+9$ & - & $6.8 E+3$ \\
\hline
\end{tabular}

(a) Where $5.5 \mathrm{E}-2=5.5 \times 10^{-2}$.

(b) A dash indicates that no transfer iactors from blood have been defined by the ICRP, thus no dose estimates are made.

(c) $+D$ means plus short-lived daughtersi. 
The NRC based the near-surface disposal limits in 10 CFR Part 61 on total body dose only. However, we have shown organ-specific doses for bone, lungs, and G.I. Tract for completeness.

\section{DETERMINATION OF POTENTIAL LOW-LEVEL WASTE LIMITS}

The low-level waste-disposal limits developed by the NRC are based on a complex exposure-scenario analysis and total-body dose. Because it is not our intent to duplicate their entire analysis, we developed the potential disposal limits shown in Table 4 by ratio of total-body doses to ${ }^{59} \mathrm{Ni}$, a long-lived activation product considered by the NRC. The ratio technique is simply:

$$
\left(\frac{\text { Dose }{ }^{59} N i}{\text { Dose }}\right) \cdot\left(L^{59_{N i}}\right) \cdot\left(e^{\lambda_{i} t}\right)=L_{i}
$$

where Dose ${ }^{59} \mathrm{Ni}$ - scenario-specific total-body dose-conversion factor for ${ }^{59} \mathrm{Ni}(1.8 \mathrm{E}+4 \mathrm{mrem} / \mathrm{yr} / \mu \mathrm{Ci} / \mathrm{g})$

Dose $i$ - scenario-specific total-body dose conversion factors for $\mathrm{radionuclide} \mathrm{i}, \mathrm{mrem} / \mathrm{yr} / \mu \mathrm{Ci} / \mathrm{g}$

${ }^{\mathrm{L}_{59}}{ }_{\mathrm{Ni}}$ - 1ow-level waste-disposal 1 imit for ${ }^{59} \mathrm{Ni}$ (Class $\mathrm{A}$ wastes $=2.2 \mathrm{Ci} / \mathrm{m}^{3}, \mathrm{Class} \mathrm{C}$ wastes $=22 \mathrm{Ci} / \mathrm{m}^{3}$ )

$\lambda_{i}$ - decay constant for radionuclide $i$, years

$t \cdot \operatorname{time}=100$ years

$L_{i}$ - potential low-level waste-disposal limit for radionuclide $i, \mathrm{Ci} / \mathrm{m}^{3}$.

The exponential term in Equation 4 is to correct the disposal 1 imit for 100 years of decay during the institutional control period at a low-level 
radioactive-waste burial ground. For long-lived radionuclides, the exponential term reduced to unity.

As a check of the adequacy of our technique, we compared disposal 1 imits developed by our method with those reported by the NRC for ${ }^{60} \mathrm{Co}$ and ${ }^{63} \mathrm{Ni}$, as shown in Table 4. This comparison shows good agreement to within about 15\%.

\section{IABLE 4. Potential Low-Leve1 Waste-Disposal Limits for Fusion Wastes}

\begin{tabular}{|c|c|c|c|c|c|}
\hline \multirow[b]{2}{*}{ Radionuclide } & \multirow{2}{*}{$\begin{array}{c}\text { Total Body } \\
50-\text { Year Dose } \\
\text { Commitment } \\
\text { (mrem } \angle y r / u c j<g \text { ( })\end{array}$} & \multicolumn{2}{|c|}{ 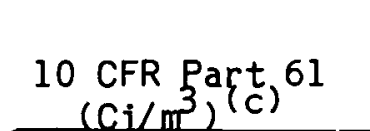 } & \multicolumn{2}{|c|}{$\begin{array}{c}\text { Estimated } \\
\text { Disposa] Limits } \\
\left(\mathrm{ci} / \mathrm{m}^{3}\right) \\
\end{array}$} \\
\hline & & Class A & class $c$ & Class A & Class $C$ \\
\hline${ }^{60} \mathrm{Co}$ & $2.7 E+7^{(c)}$ & 700 & $*^{(d)}$ & 600 & * \\
\hline${ }^{59} \mathrm{Ni}$ & $1.8 \mathrm{E}+4$ & 2.2 & 22 & 2 & 20 \\
\hline $63 \mathrm{Ni}$ & $2.7 E+4$ & 3.5 & 35 & 3 & 30 \\
\hline${ }^{10} \mathrm{Be}$ & $5.5 \mathrm{E}+2$ & $-(e)$ & - & 70 & 700 \\
\hline $26 \mathrm{Al}$ & $2.1 \mathrm{E}+5$ & - & - & 0.2 & 2 \\
\hline $32 \mathrm{Si}$ & $8.6 \mathrm{E}+3$ & - & - & 6 & 60 \\
\hline${ }^{53} \mathrm{Mn}$ & $6.3 E+3$ & - & - & 6 & 60 \\
\hline $92 \mathrm{Nb}$ & $1.2 E+4$ & - & - & 3 & 30 \\
\hline $93 Z r+D(f)$ & $1.8 \mathrm{E}+3$ & - & - & 2 & 20 \\
\hline $93 \mathrm{Mo}$ & $1.5 \mathrm{E}+5$ & - & - & 0.3 & 3 \\
\hline $113 \mathrm{Sn}$ & $1.8 \mathrm{E}+3$ & * & * & * & * \\
\hline $123 \mathrm{Sn}$ & $3.7 \mathrm{E}+3$ & * & * & * & * \\
\hline $205 \mathrm{pb}$ & $8.3 E+5$ & - & - & 0.05 & 0.5 \\
\hline
\end{tabular}

(a) Ingestion dose factors for the Intruder/Agriculture scenario were calculated using the PABLM (Napier, Kennedy, and Soldat) computer program.

(b) For activated metals, the values shown should be multiplied by ten.

(c) Where $3.7 \mathrm{E}+7=3.7 \times 10$.

(d) An * means no disposal 1 imit is set on radionuclides with halflives less than five years.

(e) A dash indicates that 10 CFR Part 61 did not 1 ist the radionuclide shown and implied it to be $\mathrm{Cl}$ ass $\mathrm{A}$ waste sithout a concentration limit.

(f) $+D$ means plus short-lived daughters. 


\section{SUMMARY AND DISCUSSION OF RESULTS}

The potential $\mathrm{Cl}$ ass $\mathrm{C}$ disposal 1 imits, resulting from our analysis range from unlimited quantities of the short-1ived ${ }^{113} \mathrm{Sn}$ and ${ }^{123} \mathrm{Sn}$ to 0.5

$\mathrm{Ci} / \mathrm{m}^{3}$ of ${ }^{205} \mathrm{~Pb}$. It should be noted that 10 CFR Part 61 provides that a radionuclide not shown in its concentration tables can be considered to be a Class $A$ waste, with no disposal concentration limit. However, we feel that the potential 1 imits proposed in this paper more adequately reflect the interest in the extremely long-lived radionuclides that may result from the fusion fuel cycle. Furthermore, our calculated potential limits are intended to be consistent with the concern reflected by the NRC in their limit on ${ }^{59} \mathrm{Ni}$, which has an 80,000 -years half-life. 


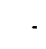


APPENDIX

EMISSION DATA LISTINGS FOR FUSION ACTIYATION PRODUCTS 


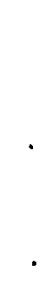




\section{EMISSION DATA LISTINGS FOR FUSION ACTIVATION PRODUCTS}

To calculate the energy absorbed per disintegration for the ten fusion activation products considered in this study, emission data listings are required. These listings show the type of radiation, the energy of the radiation (in $\mathrm{MeV}$ ), and the intensity of the radiation (in \%). The reference for the emission data is Kocher (1981). Listings of the emission data for the radionuclides shown in Table 1 are given in Table A.l through A.10.

IABLE A.1. Emission Data for ${ }^{10} \mathrm{Be}(1.6 \mathrm{E}+6 \mathrm{yr})$
$\frac{\text { Betas (Kocher } 1981 \mathrm{De} 69)}{0.556} \frac{\text { Intensity }(\%)}{100 \%}$

IABLE A.2. Emission Data for ${ }^{26} \mathrm{Al}(7.2 \mathrm{E}+5 \mathrm{yr})$

\begin{tabular}{|c|c|c|}
\hline \multirow[b]{2}{*}{ Type } & \multicolumn{2}{|c|}{ Photons (Kecher 1981 p. 70 ) } \\
\hline & Energy $(\mathrm{MeV})$ & Intensity $(\%)$ \\
\hline \multirow[t]{7}{*}{$\begin{array}{l}\text { X-rays } \\
\text { Gammas }\end{array}$} & $\begin{array}{l}0.00125 \\
0.130 \\
1.808 \\
2.938\end{array}$ & $\begin{array}{r}0.44 \\
2.50 \\
99.76 \\
0.24\end{array}$ \\
\hline & \multicolumn{2}{|c|}{ Positrons (Kocher 1981 R. 70) } \\
\hline & Energy $(\mathrm{MeV})$ & Intensity $(\%)$ \\
\hline & 1.174 & 81.8 \\
\hline & \multicolumn{2}{|c|}{ Electrons (Kocher 1981 p. 70) } \\
\hline & Energy $(\mathrm{MeV})$ & Intensity $(\%)$ \\
\hline & 0.00118 & 16.2 \\
\hline
\end{tabular}

A. 1 
IABLE A.3. Emission Data for ${ }^{32} \mathrm{Si}(3.3 \mathrm{E}+2 \mathrm{yr})$

Betas (Kocher 1981_ D. 70)

Energy (MeV) Intensity $(\%)$

$0.213 \quad 100$

IABLE A.4. Emission Data for ${ }^{53} \mathrm{Mr}(3.7 \mathrm{E}+6 \mathrm{yr})$

Photons (Kocher 1981_p. 75)

Type Energy (MeV) Intensity (\%)

$\begin{array}{lll}X \text {-rays } & 0.00540 & 7.43\end{array}$

$0.00541 \quad 14.7$

$0.006 \quad 2.95$

Electrons (Kocher 1981 D. 75)

Energy (MeV) Intensity (\%)

$0.00054 \quad 142$

$0.00478 \quad 63.9$

IABLE A.5. Emission Data for ${ }^{92} \mathrm{Nb}(3.6 \mathrm{E}+7 \mathrm{yr})$

Photons (Kocher 1981_D. 102)

Iype Eneroy (MeV) Intensity (\%)

$\begin{array}{lll}X \text {-rays } & 0.0158 & 53.5\end{array}$

$\begin{array}{llr}\text { Gamma } & 0.0177 & 9.9 \\ & 0.561 & 99.7\end{array}$

$0.934 \quad 99.9$

Electrons (Kocher 1981 R. 102 )

Energy (MeV) Intensity (\%)

$\begin{array}{lc}0.002 & 100 \\ 0.013 & 23.0 \\ 0.543 & 0.26\end{array}$

A. 2 
IABLE A.6. Emission Data for ${ }^{93} \mathrm{Zr}(1.5 \mathrm{E}+6 \mathrm{yr})$ Betas (Kocher 1981 D. 104) Energy (MeV) Intensity (\%) $0.0651 \quad 100$

IABLE A.7. Emission Data for ${ }^{93}$ Mo $(3.5 E+3 \mathrm{yr})$ Photons (Kocher 1981 D. 104)

Iype Energy (MeV) Intensity (\%) X-rays 0.0165 0.0166 18.1 0.0186 34.8 10.0

Electrons (Kocher 1981 D. 104) Energy (MeV) Intensity (\%)

$\begin{array}{ll}0.0022 & 98 \\ 0.014 & 21\end{array}$

IABLE A.8. Emission Data for ${ }^{113} \mathrm{Sn}$ (115.1 d) Photons (Kocher 1981 P. 104)

Type Energy (MeV) Intensity (\%)

$x$-rays

$\begin{array}{lc}0.0240 & 20.7 \\ 0.0242 & 39.0 \\ 0.255 & 1.93\end{array}$

Electrons (Kocher 1981 D. 115) Eneroy (MeV) Intensity (\%)

0.0028

0.020

85

12.8 
IABLE A.2. Emission Data for ${ }^{123} \mathrm{Sn}$ (129 d) Photons (Kocher 198] R. 122)

Type Energy (MeV) Intensity (\%)

$\begin{array}{lll}X \text {-rays } & 1.089 & 0.6\end{array}$

Betas (Kocher 1981 D. 122)

Energy (MeV) Intensity (\%)

$0.308 \quad 0.6$

$1.397 \quad 99.4$

IABLE A.10. Emission Data for ${ }^{205} \mathrm{Pt}$ (1.51E+7 yr)

Photons (Kocher 1981_R. 182)

Type Energy (MeV) Intensity (\%)

$\begin{array}{lll}X \text {-rays } & 0.010 & 22.7\end{array}$

Electrons (Kocher 1981 p. 182)

Energy (MeV) Intensity (\%)

0.00778

A. 4 


\section{REFERENCES}

Eederal Register. Vo1. 47, No. 248, p. 57446-82(December 27, 1982). "Nuclear Regulatory Commission, 10 CFR Parts 2, 19, 20, 21, 30,40,51,61, 70, 73, and 170, Licensing Requirements for Land Disposal of Radioactive Waste Final Rule."

International Commission on Radioloical Protection (ICRP). 1959. Recommendations of the International Commission on Radiological Protection. ICRP Publication 2, Pergamon Press, New York.

Kocher, D. C. 1981. Radioactive Decay Data Tables, A Handbook of Decay Data for Application to Radiation Dosimetry and Radiological Assessments. DOE/TIC-11026. Technical Information Center. U.S. Department of Energy, Washington, D.C.

Napier, B. A., W. E. Kennedy, Jr., and J. K. Soldat. 1980. PABLM - A Computer Program to Calculate Accumulated Radiation Doses From Radionuclides in the Environment. PNL-3180, Pacific Northwest Laboratory, Richland, Washington.

U.S. Department of Energy. 1983 a. Damage Analysis and Fundamental Studies, Quarterly Progress Report October-December 1982. DOE/ER-0046/12, p. 69. Assistant Secretary for Energy Technology, Office of Fusion Energy, Washington, D.C.

U.S. Department of Energy. 1983 b. Damage Analysis and Fundamental Studies, Quarterly Progress Report January-May 1983. DOE/ER-0046/13, p. 63. Assistant Secretary for Energy Technology, Office of Fusion Energy, Washington, D.C.

U.S. Nuclear Regulatory Commission. 1977. Draft Regulatory Guide 1.109, Calculation of Annual Doses to Man from Routine Releases of Reacter Effluents for the Purpose of Evaluating Compliance with 10 CFR Part 50, Appendix I. Office of Standards Development, Washington, D.C.

U.S. Nuclear Regulatory Commission. 1981. Draft Environmental Impact Statement on 10 CFR Part 61, "Licensing Requirements for Land Disposal of Radioactive Waste." NUREG-0782, Vols. 1-4, Washington, D.C.

U.S. Nuclear Regulatory Commission. 1982. Einal Environmental Impact Statement on 10 CFR Part 61, "Licensing Requirements for Land Disposal of Radioactive Waste." NUREG-0945, Washington, D.C. 
.

. 


\section{DISTRIBUTION}

No. of

Copies

OFFSITE

27 DOE Technical Information Center

\section{ONSITE}

DOE Richland Operation's Office

H. E. Ransom

5 Hanford Engineering and Development Laboratory

D. G. Doran

F. M. Mann (2)

J. L. Straalsund

H. H. Yoshikawa

40 Pacific Northwest Laboratory

J. B. Brown

T. D. Chikalla

L. G. Faust

W. A. G1ass

W. E. Kennedy, Jr. (15)

M. R. Kreiter

J. M. Latkovich

W. D. McCormack

B. A. Napier

I. C. Nelson

A. M. Platt

J. V. Robinson

R. G. Schreckhise (2)

J. M. Selby

J. K. Soldat

S. L. Stein

C. M. Unruh

E. C. Watson

Publishing Coordination (2)

Technical Information (5) 


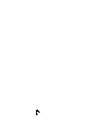

